[Transaction ]

\title{
Optimization of Wool Dyeing with Yellow Dye from Carthamus Tinctorius $\mathbf{L}$.
}

\author{
Younsook Shin ${ }^{\dagger} \cdot$ Kyunghee Son · Dong II Yoo* \\ Dept. of Clothing \& Textiles, Chonnam National University/ \\ Human Ecology Research Institute, Chonnam National University \\ *School of Applied Chemical Engineering, Chonnam National University \\ Received November 10, 2009; Revised November 25, 2009; Accepted December 3, 2009 \\ 홍화 황색소를 이용한 모염색의 최적화 \\ 신윤숙 · 손경희 · 류동일* \\ 전남대학교 의류학과/생활과학연구소, *전남대학교 응용화학공학부 \\ 접수일(2009년 11월 10일), 수정일(2009년 11월 25일), 게재확정일(2009년 12월 3일)
}

\begin{abstract}
This study investigated the adsorption of safflower yellow dye on wool protein fiber and the optimum dyeing conditions to test color reproducibility. In addition, the effects of mordants on dye adsorption, color, fastness, and photofading rate were also studied. The prepared dye in powder form was characterized with UV-vis spectroscopy and FT-IR spectrometric analysis. The color of dyed fabrics was characterized by CIE $\mathrm{L}^{*} \mathrm{a}{ }^{*} \mathrm{~b} *$ coordinates, $\mathrm{H}$ V/C, and K/S values. The color reproducibility of the dyed wool fabrics was examined. The amount of dye adsorption increased and also, the shade of the dyed wool fabrics became deeper and more saturated with increasing temperature, time, and dye concentration. The maximum color strength was obtained at $\mathrm{pH}$ 3.0. The shade of dyed wool fabrics ranged from light yellow to dark mustard yellow as the $\mathrm{pH}$ of the dye bath shifted from alkaline to acidic. Color reproducibility was reliable with color differences in the range of $0.53 \sim 1.75$. Fastness to dry cleaning was relatively good at $4 / 5$ rating irrespective of mordanting. $\mathrm{Fe}$ and $\mathrm{Cu}$ mordants showed the least color change of the dyed wool fabrics after exposure to light. Mordants did not contribute to improve dye uptake and color fastness, although they made variations in color tone. Safflower yellow dye can be used satisfactorily without mordants and will not cause damage to the environment.
\end{abstract}

Key words: Adsorption, Wool, Safflower yellow dye, UV-vis spectroscopy, FT-IR analysis; 염착, 모, 홍화 황색소, UV-vis 분광분석, FT-IR 분석

\footnotetext{
Corresponding author

E-mail: yshin@chonnam.ac.kr

This research was supported by Basic Science Research Program through the National Research Foundation of Korea (NRF) funded by the Ministry of Education, Science and Technology (No. 20090091276).
}

\section{Introduction}

Currently, interests in natural dyes are growing due to the depletion of natural resources, environmental problem, health hazards of synthetic dyes, and so on. Natural dyes are derived from renewable resources and have less harm to human and environment. How- 
ever, they have limitations for commercial use such as lack of standardization, low fastness, reproducibility of shade, and secure availability of raw materials. Using raw materials for dyeing causes color variation from batch to batch. For easier dyeing process and better quality control of end products, natural dyes in standardized form as synthetic dyes should be available. The present dyeing process needs optimization with dyes in standardized form to apply natural dyes in modern textile dyehouses (Bechtold et al., 2007). It is well known that the petals of safflower (Carthamus Tinctorius L.) contain red (carthamin) and yellow pigments. The red pigment used mainly in cosmetics and textiles, while the yellow pigments have been hardly used as a natural dye for textiles. Yellow pigments are used as food colorants for juices, yogurt, gelatin desserts, candy, beverages, dairy products, and confectionaries (Saito et al., 2005; Yoon et al., 2003). Compared to carthamin, larger quantities of the yellow pigments are present in safflower and are more stable under UV light (Kanehira \& Saito, 2001), and thus having its great potential as a yellow natural dye for textiles, an area of research yet to be fully explored. Wool was chosen as a textile substrate because it showed good affinity and fastness in preliminary dyeing experiments.

In this study, the adsorption of safflower yellow dye on wool protein fiber was investigated to characterize dyeing properties. And, the effect of mordants on dye adsorption, color, and fastness was also studied. The prepared dye in powder form was characterized with UV-vis spectroscopy and FT-IR. The color of dyed fabrics was characterized by CIE L*a*b* coordinates, $\mathrm{H}$ V/C, and K/S value. Color reproducibility of the dyed wool fabrics was examined.

\section{Experimental}

\section{Materials}

The fabric was scoured $100 \%$ wool (plain weave, $72 \times 69 / \mathrm{inch}^{2}, 102 \mathrm{~g} / \mathrm{m}^{2}, 0.25 \mathrm{~mm}$ thickness). Dried safflower petals were purchased commercially in an oriental medicine market. Five mordants used were aluminum sulfate hydrate $\left(\mathrm{Al}_{2}\left(\mathrm{SO}_{4}\right)_{3} \cdot 13 \mathrm{H}_{2} \mathrm{O}\right)$, copper sul- fate hydrate $\left(\mathrm{CuSO}_{4} \cdot 5 \mathrm{H}_{2} \mathrm{O}\right)$, stannous sulfate $\left(\mathrm{SnSO}_{4}\right)$, iron (II) sulfate hydrate $\left(\mathrm{FeSO}_{4} \cdot 7 \mathrm{H}_{2} \mathrm{O}\right)$, and potassium dichromate $\left(\mathrm{K}_{2} \mathrm{Cr}_{2} \mathrm{O}_{7}\right)$. Chemicals were reagent grade.

\section{Preparation of Colorant Powders}

Safflower yellow colorants was extracted from dried safflower petals in a liquor ratio of 1:100 in distilled water at $40^{\circ} \mathrm{C}$ for $2 \mathrm{hrs}$, two times, using a constant temperature shaking bath. The first and second extracts were mixed together, filtered, concentrated to $10 \%$ of original volume at $65^{\circ} \mathrm{C}$ under vacuum, and freezedried at $-40^{\circ} \mathrm{C}$ to obtain colorant powders with a yield of approximately $34 \%$. The prepared powder dye was used for dyeing without further purification. The $\mathrm{pH}$ value of the aqueous colorant extract was 5.8.

\section{Dyeing and Mordanting}

To optimize dyeing process, dye uptake was studied at different temperatures $\left(30,50,70,90^{\circ} \mathrm{C}\right)$, times $(10,30,40,60 \mathrm{~min})$, dye concentrations $(0.1,0.2,0.6$, $1.0,1.5,2.0 \mathrm{~g} / 100 \mathrm{~m} \ell$ ), and $\mathrm{pH}$ of dye bath (3 11) at liquor ratio of $1: 100$ in an automatic laboratory dyeing machine (Ahiba Nuance, Datacolor International, USA). The dyed fabrics were rinsed with distilled water until rinsing liquor became clear. The $\mathrm{pH}$ of dyeing solution was adjusted using acetic acid and sodium hydroxide.

Post-mordanting was carried out at a liquor ratio of $1: 100$ in $1 \%$ (owf) solution of mordant at $60^{\circ} \mathrm{C}$ for 30 min using an automatic laboratory dyeing machine.

\section{Characterization}

UV-vis spectrum was obtained using UV-vis spectrophotometer (Agilent 8453, Agilent Technologies Mfg GmbH \& Co., Germany). FT-IR (Fourier Transform Infrared spectrometer, Nicolet 520, USA) analysis was done to characterize the prepared yellow dye. The dyed fabrics was evaluated in terms of K/S and CIE L*a*b* coordinates with a Macbeth Coloreye 3100 spectrophotometer under Illuminant $\mathrm{D}_{65}$ with a $10^{\circ}$ standard observer. $\mathrm{H}$ V/C values were obtained from $\mathrm{L}, \mathrm{a}^{*}, \mathrm{~b}^{*}$ values using the CIE Munsell conver- 
sion program.

Fastness to dry cleaning of the dyed samples was evaluated by AATCC method 61-1989. Light fastness was assessed in terms of color difference $(\Delta \mathrm{E})$ and color change against the appropriate grey scale according to AATCC method 16-1998 with FadeOmeter (Atlas Electric Devices Co, USA). Color differences after irradiating for 5, 10, 20, and 40 hours were measured to get fading curve.

\section{Results and Discussion}

\section{Characterization of Dye}

<Fig. 1> shows the UV-vis absorption spectrum of safflower yellow dye solution. Maximum absorption

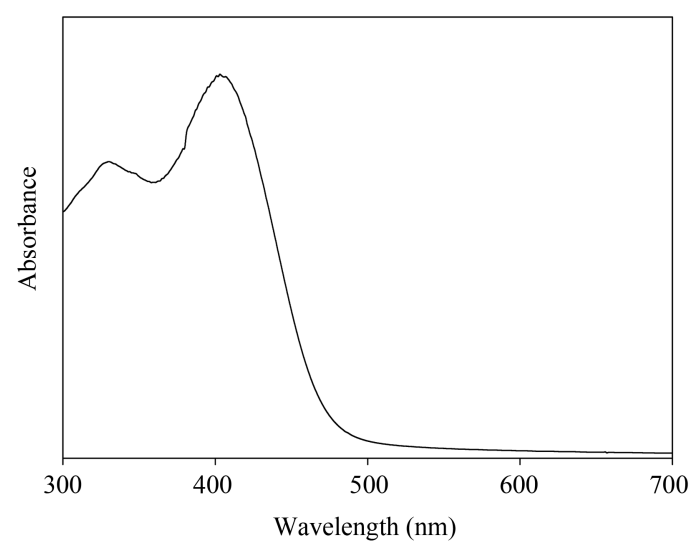

Fig. 1. UV-vis absorption spectrum of safflower yellow dye.<smiles>CC(C)(C)C1(O)C(O)=C(C=Cc2ccc(O)c(O)c2)C(=O)C(C(=O)C=CC(=O)C=Cc2ccccc2)=C1O</smiles>

Safflower yellow B peak ( $\lambda$ max) appeared at $400 \mathrm{~nm}$. It was reported $\lambda \max$ at $410 \mathrm{~nm}$ and $399 \mathrm{~nm}$ for safflower yellow B and hydroxylsafflower yellow A solving in methanol, respectively (Yoon et al., 2003). Safflower yellow pigments contain many components such as hydroxylsafflower yellow A, safflower yellow A, safflower yellow B, safflomin A, safflomin B, tinctormin, etc (Saito et al., 2005; Yoon et al., 2003). The structures of safflower yellow B and safflomin A are present in $<$ Fig. 2>. All of these yellow pigments belong to the C-glucosyl quinochalcone family of flavonoids. <Fig. 3> shows FT-IR spectrum of yellow dye. Characteristic peaks corresponding to $\mathrm{OH}$ stretching at $3388 \mathrm{~cm}^{-1}$, conjugated $\mathrm{C}=\mathrm{O}$ stretching at $1624 \mathrm{~cm}^{-1}, \mathrm{C}-\mathrm{O}$ stretching at $1077 \mathrm{~cm}^{-1}$ were appeared. Peak at $2929 \mathrm{~cm}^{-1}$ might be due to $\mathrm{CH}_{2}$ or $\mathrm{CH}_{3}$ stretching. Considering

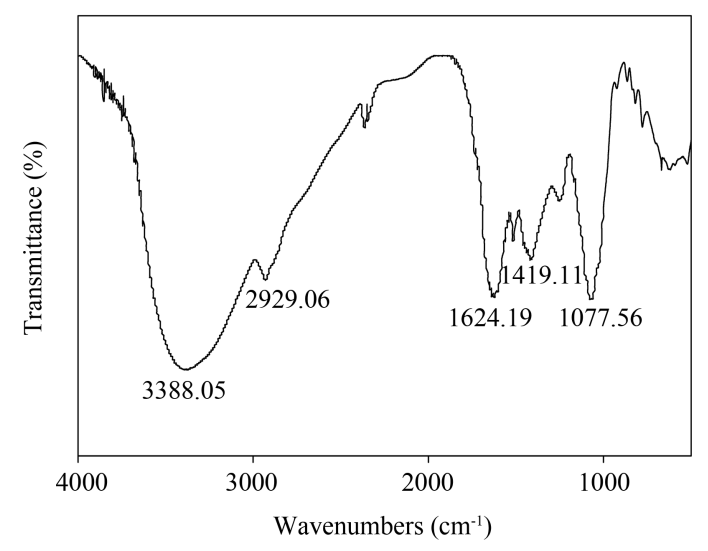

Fig. 3. FT-IR spectrum of safflower yellow dye.<smiles>O=C(/C=C/c1ccc(O)cc1)C1=C(O)C(C(Cl)(Cl)Cl)=C(O)C(O)(Cl)C1=O</smiles>

Safflomin A

Fig. 2. Structure of safflower yellow pigments. 
Table 1. Effect of dyeing temperature and time on the CIE $L^{*} a^{*} b^{*}$ color coordinates and $\mathrm{K} / \mathrm{S}$ values $(0.6 \%$ conc.)

\begin{tabular}{c|c|c|c|c|c}
\hline \hline Temp/time $\left({ }^{\circ} \mathrm{C} / \mathrm{min}\right)$ & $\mathrm{L}^{*}$ & $\mathrm{a}^{*}$ & $\mathrm{~b}^{*}$ & $\mathrm{H} \mathrm{V} / \mathrm{C}$ & $\mathrm{K} / \mathrm{S}$ value $(400 \mathrm{~nm})$ \\
\hline $30 / 60$ & 82.17 & -1.13 & 23.73 & $5.2 \mathrm{Y} 8.1 / 3.1$ & 1.21 \\
\hline $50 / 60$ & 77.26 & 0.64 & 38.71 & $4.6 \mathrm{Y} 7.7 / 5.4$ & 3.31 \\
\hline $70 / 60$ & 71.14 & 2.93 & 51.47 & $4.4 \mathrm{Y} 7.1 / 7.3$ & 8.44 \\
\hline $90 / 10$ & 69.39 & 3.55 & 53.82 & $4.4 \mathrm{Y} 6.9 / 7.7$ & 10.46 \\
\hline $90 / 30$ & 65.10 & 6.02 & 54.38 & $3.6 \mathrm{Y} 6.5 / 7.9$ & 14.03 \\
\hline $90 / 40$ & 63.42 & 6.98 & 54.11 & $3.2 \mathrm{Y} 6.3 / 7.9$ & 15.52 \\
\hline $90 / 60$ & 61.28 & 8.31 & 53.19 & $2.7 \mathrm{Y} 6.1 / 7.8$ & 16.38 \\
\hline
\end{tabular}

the chemical structures of safflower yellow pigments (Shin et al., 2008), it is speculated that the prepared yellow dye contains various yellow colorants.

\section{Optimization of Dyeing Conditions}

$<$ Table 1> shows the effect of temperature and time on the dye uptake and color of wool fabrics. Dyeing was carried out at $\mathrm{pH} 5.8$ without adjustment. Dye uptake, expressed as $\mathrm{K} / \mathrm{S}$ at the maximum absorption wavelength, increased with the increase of temperature. Adsorption increased slowly below $50^{\circ} \mathrm{C}$ and then rapidly with a maximum color strength at $90^{\circ} \mathrm{C}$. Optimum dyeing temperature was set at $90^{\circ} \mathrm{C}$. At higher temperature, opening up pores in the amorphous region of wool fiber leads to increase the accessibility of dye molecules. The diffusion of dye molecules takes place more easily into the wool fibers and more dyes would adsorb on the wool fiber. The effect of dyeing time was investigated up to $60 \mathrm{~min}$. As expected, higher dye uptake was obtained with longer dyeing time. Adsorption occurred rapidly within the first 10min and then increased slowly, thereafter reached to equilibrium at 40 60min. Optimum dyeing time for wool was set to 40min. Adsorption is rapid at first due to easy accessibility of the sites but becomes slower as the dye molecules have to find the more remote sites of attachment. With increasing temperature and time $\mathrm{L}^{*}$ decreased, while $\mathrm{a}^{*}$ and $\mathrm{b}^{*}$ increased. This indicates that the color of dyed wool fabrics became darker and stronger yellow with slight increase of red character. Saturation (C) increased and hue $(\mathrm{H})$ was varied in the range of Y color. The Munsell color values of wool fabrics follow a general trend of greater saturation and darker

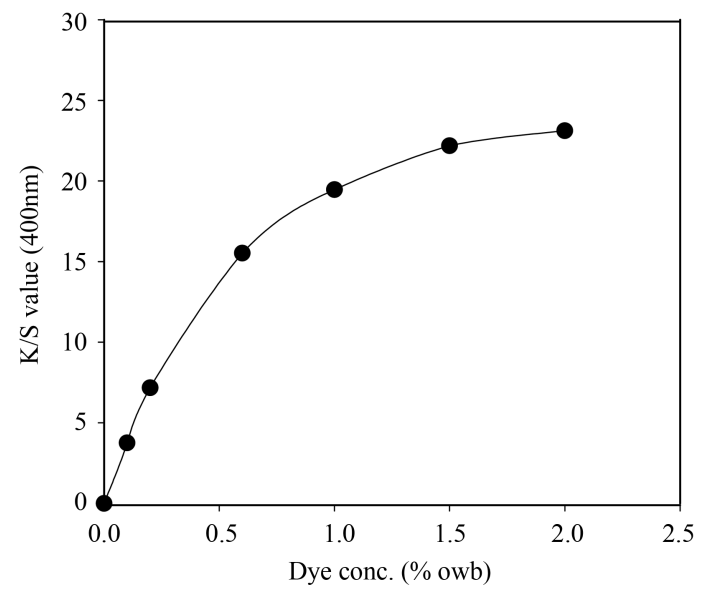

Fig. 4. Effect of dye concentration on the dye uptake $\left(90^{\circ} \mathrm{C}, 40 \mathrm{~min}\right)$.

hue with increasing temperature and time.

Dye uptake increased progressively as colorant concentration increased as shown in $\langle$ Fig. 4$\rangle$. With increasing concentration, more dye transferred to the fabric and the depth of color became stronger. This could be attributed to the population effect of dye molecules presented in the dye bath at higher concentration (Deo \& Desai, 1999).

<Fig. 5> shows the effect of $\mathrm{pH}$ on dye uptake at $90^{\circ} \mathrm{C}$ for $40 \mathrm{~min}$ in $0.6 \%$ dye concentration. It was observed a bathochromic shift from 400 to $420 \mathrm{~nm}$ below pH 4.5 (Kim \& Lee, 1996) and K/S value reached maximum at $\mathrm{pH}$ 3.0. Dye uptake in alkaline conditions was very low and increased sharply in acidic condition, reaching a maximum color depth at $\mathrm{pH}$ 3.0. This result attributed to the structural features of colorants and wool fiber. Wool protein fibers contain free carboxyl groups and amino groups and so, 


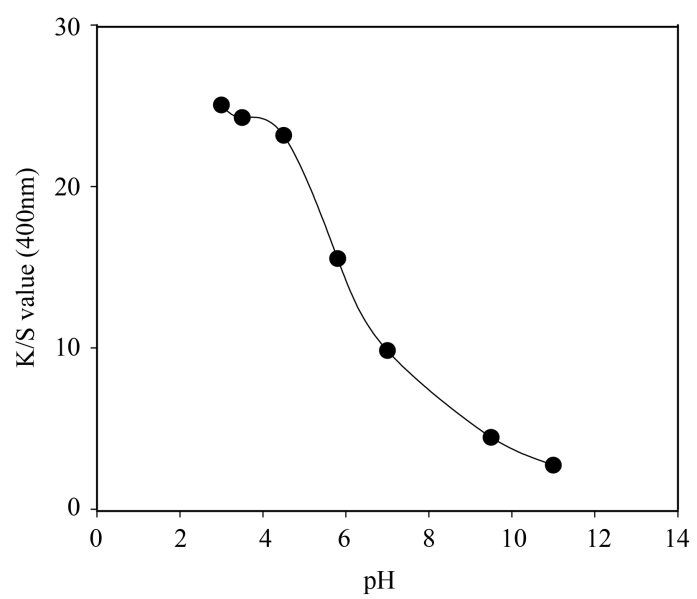

Fig. 5. Effect of $\mathrm{pH}$ on the dye uptake $\left(90^{\circ} \mathrm{C}, 40 \mathrm{~min}\right.$, $0.6 \%$ conc.).

electrical charges on the wool fiber are differed depending on $\mathrm{pH}$. In acidic solution, (+) charges on amino groups in wool fibers are formed dominantly. On the other hand, yellow colorants exist as aglycons in acidic condition with (-) charges forming on the surface of colorants (Cho, 1997). The (-) charged colorants formed ionic bonding with amino groups $\left(\mathrm{NH}_{3}{ }^{+}\right)$ in wool fibers. Below the isoelectric point of wool keratin (about pH 4.9) (Kim \& Lee, 1996), more (+) charges are formed on wool fibers and more dye sites are available, increasing dye uptake. In alkaline condition, more (-) charges on carboxyl groups and less (+) charges on wool fibers are formed and thus lower

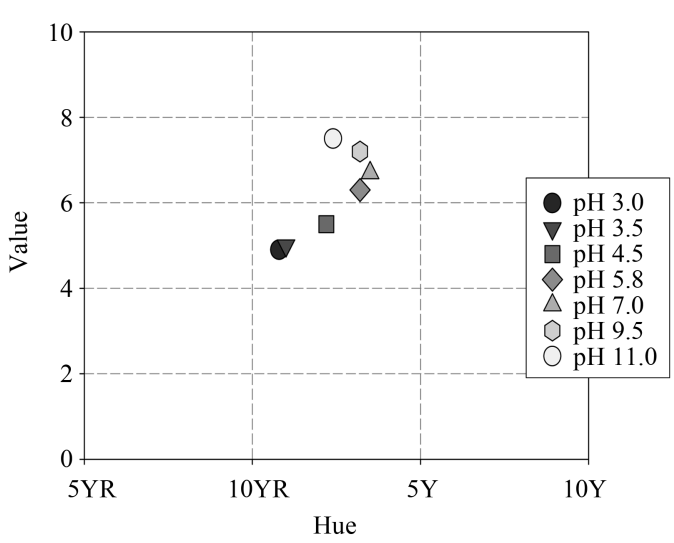

dye uptake. It is speculated that the adsorption of safflower yellow dye on wool would be involved mainly by ionic bonding.

<Fig. 6> shows the influence of $\mathrm{pH}$ of dye bath on Munsell color coordinates. In acidic dye bath, the hue of dyed wool was shifted toward YR color with decrease in lightness (V) and marginal change in saturation (C). On the other hand, in alkaline dye bath Y color was not changed significantly, while saturation decreased much and brightness increased. The color values of wool fabrics follow a general trend of greater saturation and darker hue with decreasing $\mathrm{pH}$ of the dye bath. Saturation reached maximum value at $\mathrm{pH}$ 3.5 4.5. The color of dyed wool fabrics appeared from light yellow to deeper and more saturated mustard color as the $\mathrm{pH}$ of dye bath shifted from alkaline to acidic.

From the above results, optimum dyeing conditions were set at $90^{\circ} \mathrm{C}$ for $40 \mathrm{~min}$ in $\mathrm{pH} 3.5$ of dye bath. Reproducibility of the laboratory dyeing process was tested at the optimum conditions with $0.6 \%$ dye concentration and the results are shown in <Table 2>. Color differences $\left(\Delta \mathrm{E}^{*}\right)$ between dyeing batches show in the range of $0.53 \sim 1.75$. The color difference of dyed wool was less than that of dyed silk (1.11 2.01) for same colorants (Shin et al., 2008). Colorants in powder form are considered more advantageous and better control of dyeing process than liquid extract, leading to more reliable dyeing results.

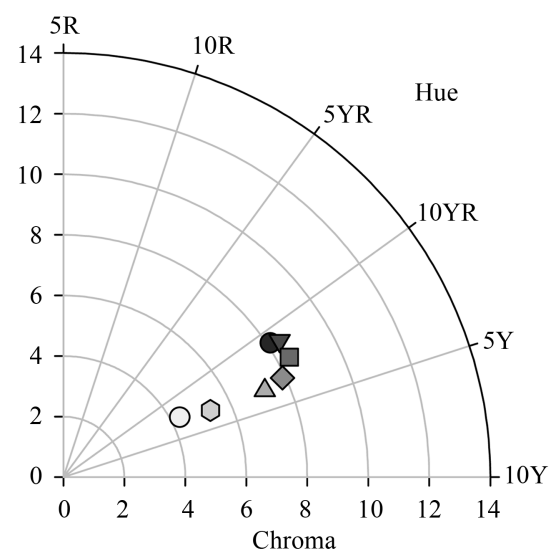

Fig. 6. Color variation of dyed fabrics depending on $\mathrm{pH}$ of dye bath $\left(90^{\circ} \mathrm{C}, 40 \mathrm{~min}, 0.6 \%\right.$ conc.). 
Table 2. Variations in CIE L* a* $\mathrm{b}^{*}$ color coordinates and $\mathrm{K} / \mathrm{S}$ values of test dyeings $\left(90^{\circ} \mathrm{C}, 40 \mathrm{~min}, 0.6 \%\right.$ conc., $\left.\mathrm{pH} 3.5\right)$

\begin{tabular}{c|c|c|c|c|c|c}
\hline \hline $\begin{array}{c}\text { Batch } \\
\text { no. }\end{array}$ & $\begin{array}{c}\text { K/S value } \\
(420 \mathrm{~nm})\end{array}$ & $\mathrm{L}^{*}$ & $\mathrm{a}^{*}$ & $\mathrm{~b}^{*}$ & $\mathrm{H} \mathrm{V/C}$ & $\Delta \mathrm{E}^{*}$ \\
\hline 1 & 26.33 & 50.64 & 13.61 & 54.10 & $1.0 \mathrm{Y} \mathrm{5.0/8.4}$ & - \\
\hline 2 & 26.60 & 50.18 & 13.75 & 54.30 & $1.0 \mathrm{Y} 5.0 / 8.5$ & 0.53 \\
\hline 3 & 26.82 & 51.66 & 13.38 & 55.49 & $1.2 \mathrm{Y} 5.1 / 8.6$ & 1.75 \\
\hline
\end{tabular}

\section{Effect of Mordanting on Color and Color- fastness}

$<$ Fig. 7> shows dye uptake depending on mordant type and mordanting method. Regardless of mordant type, post-mordanting gave a little higher depth of shade (K/S), but pre- and simultaneous-mordanting methods did not increase dye uptake. So, post-mordanting method was chosen for further discussion.

The effects of post-mordanting on color and fastness of the dyed wool fabrics are presented in <Table $3>$. Mordanting of the textile material is to improve the color yield in the development of shade and to

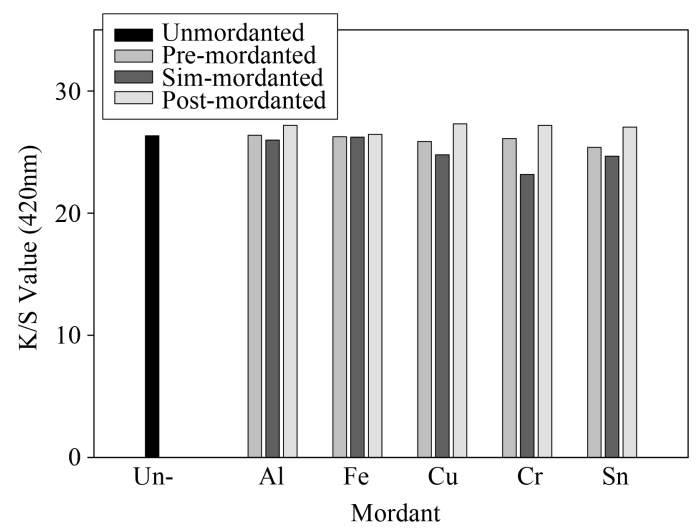

Fig. 7. Effect of mordant and mordanting method on the dye uptake $\left(90^{\circ} \mathrm{C}, 40 \mathrm{~min}, 0.6 \%\right.$ conc., $\mathrm{pH}$ 3.5). help fixation of the coloring molecule to the substrate as a link. Wool showed good affinity to safflower yellow dye and thus, the dye adsorbed onto the wool fiber followed by forming insoluble complex with metal ions in post-mordanting method. Post-mordanting increased dye uptake slightly, but different tones of Y color were developed by different mordants. Fe and $\mathrm{Cu}$ mordants gave greenish shade while $\mathrm{Cr}$ mordant produced more reddish shade on wool fabrics. The shade of wool fabric mordanted with $\mathrm{Al}$ was not much changed. Sn mordant produced the most saturated and bright yellow color. Various yellow shades with different tones could be produced by post-mordanting. Fastness to washing was relatively good as $4 / 5$ rating for both the unmordanted and mordanted wool fabrics, as shown in <Table 3>. Rating of light fastness was improved slightly by $\mathrm{Cu}$ and $\mathrm{Fe}$ mordants.

<Fig. 8> shows the effect of light exposure time on the fading rate of the unmordanted and post-mordanted wool fabrics dyed with safflower yellow dye. Fading rate was expressed by color change $\left(\Delta \mathrm{E}^{*}\right)$ depending on light exposure time. Fading rate curve is a useful indicator probing interrelationship between the physical state of a dye within a fiber and its light fastness. The fading rate curves in 〈Fig. 8$\rangle$ can be considered as Type II fading where fading initially occurs at a rapid rate followed by slower fading (Giles, 1965). This indicates that dyes are presented in aggregates inside the fiber (Cristea \& Vilarem, 2006).

Table 3. Effect of post-mordanting on Munsell color and fastness $\left(90^{\circ} \mathrm{C}, 40 \mathrm{~min}, 0.6 \%\right.$ conc., $\left.\mathrm{pH} 3.5\right)$

\begin{tabular}{c|c|c|c}
\hline \hline Mordant & $\mathrm{H} \mathrm{V} / \mathrm{C}$ & Wash fastness & Light fastness \\
\hline Control & $1.0 \mathrm{Y} \mathrm{5.0/8.4}$ & $4 / 5$ & 3 \\
\hline $\mathrm{Al}$ & $1.1 \mathrm{Y} \mathrm{5.0/8.5}$ & $4 / 5$ & 3 \\
\hline $\mathrm{Fe}$ & $2.6 \mathrm{Y} 4.4 / 6.6$ & $4 / 5$ & $3 / 4$ \\
\hline $\mathrm{Cu}$ & $1.5 \mathrm{Y} \mathrm{4.6/7.5}$ & $4 / 5$ & $3 / 4$ \\
\hline $\mathrm{Cr}$ & $7.8 \mathrm{YR} 4.1 / 7.1$ & $4 / 5$ & $2 / 3$ \\
\hline $\mathrm{Sn}$ & $0.6 \mathrm{Y} \mathrm{5.2/9.0}$ & $4 / 5$ & 3 \\
\hline
\end{tabular}




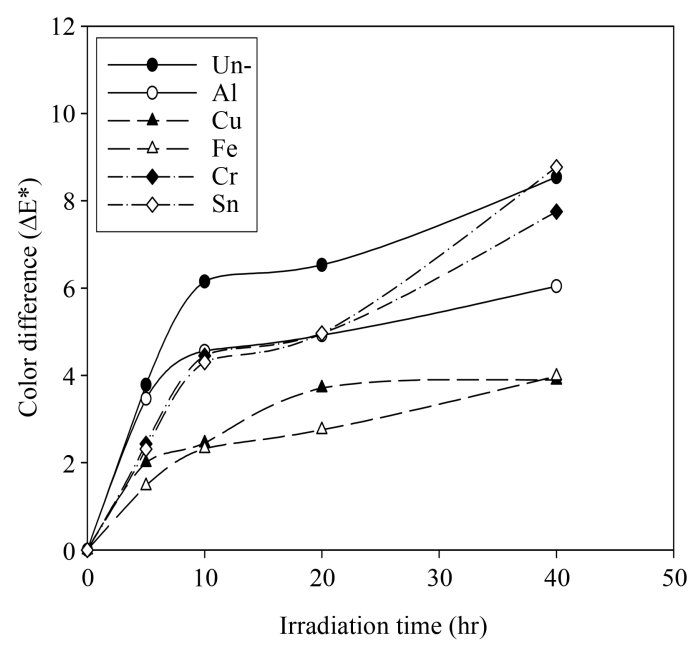

Fig. 8. Effect of irradiation time on the color difference of wool fabrics dyed with safflower yellow dye.

It was confirmed that mordants affected apparently the fading rate of dyed wool fabrics. Fe and $\mathrm{Cu}$ mordants showed the least color change of the dyed wool fabrics. Al mordant also reduced the fading rate of dyed wool fabrics. Sn and Cr mordants showed the same amount of color change with Al mordant at short light exposure time. However, as the length of light exposure increased, color change with $\mathrm{Sn}$ and $\mathrm{Cr}$ mordants got larger and became similar to the unmordanted.

Overall, mordants did not contribute to improve dye uptake and color fastness of wool fabrics dyed with safflower yellow dye, although the use of mordants gave color variations. It is thought that safflower yellow dye can be used satisfactorily without mordants and will not cause damage to the environment.

\section{Conclusions}

Dye uptake increased slowly up to $50^{\circ} \mathrm{C}$ and then rapidly with a maximum dye uptake at $90^{\circ} \mathrm{C}$. Adsorption occurred rapidly within the first $10 \mathrm{~min}$ and then increased slowly, thereafter reached to equilibrium at 40 60min. The color of wool fabrics followed a general trend of greater saturation and deeper yellow with increasing temperature and time. Dye uptake increased sharply in acidic dye bath, reaching a maximum color depth at $\mathrm{pH}$ 3.0. On the basis of the obtained results, optimum dyeing conditions for wool with safflower yellow dye was set $90^{\circ} \mathrm{C}, 40 \mathrm{~min}$, and $\mathrm{pH} 3.5$. Color reproducibility was relatively good with color difference in the range of $0.53 \sim 1.75$ between dyeing batches. Post-mordanting was not effective to increase dye uptake, but it gave various tones of yellow color with different tints on the wool fabrics. Colorfastness to dry cleaning was relatively good as $4 / 5$ rating for both the unmordanted and post-mordanted wool fabrics. $\mathrm{Fe}$ and $\mathrm{Cu}$ mordants showed the least color change after irradiation for $20 \mathrm{hrs}$.

\section{References}

Bechtold, T., Mahmud-Ali, A., \& Mussak, R. (2007). Natural dyes for textile dyeing: A comparison of methods to assess the quality of Canadian golden rod plant material. Dyes and Pigments, 75, 287-293.

Cho, K. R. (1997). Study on the natural dyes. J. of Korean Society of Dyers and Finishers, 9(5), 10-18.

Cristea, D., \& Vilarem, G. (2006). Improving light fastness of natural dyes on cotton yarn. Dyes and Pigments, 70(3), 238-245.

Deo, H. T., \& Desai, B. K. (1999). Dyeing of cotton and jute with tea as a natural dye. J. Soc Dyers Colourists, 115, 224-227.

Giles, C. H. (1965). The fading of colouring matters. Applied Chemistry, 15, 541-550.

Kanehira, T., \& Saito, K. (2001). Stability of carthamin and safflower yellow B on silk powders under continous irradiation of fluorescent or UV-C light. LebensmmittelWissenschaft und-Technologie, 34, 55-56.

Kim, G. J., \& Lee, J. M. (1996). Chemistry of dyeing. Seoul: Hyungsul Pub. Co..

Saito, S., Kusakari, T., Suda, T., Kasai, T., Kumazawa, T., Onodera, J., \& Obara, H. (2005). Efficient synthesis of analogs of safflower yellow B, carthamin, and its precursor: Two yellow and one red dimeric pigments in safflower petals. Tetrahedron, 61, 9630-9636.

Shin, Y., Son, K., \& Yoo, D. I. (2008). Dyeing properties and color of silk fabrics dyed with safflower yellow dye. J. Kor. Soc. Clothing and Textiles, 32(6), 928-934.

Yoon, J. M., Cho, M. H., Park, J. E., Kim, Y. H., Hahn, T. R., \& Paik, Y. S. (2003). Thermal stability of the pigments hydroxysafflor yellow A, safflor yellow B, and precarthamin from safflower. J. of Food Science, 68(3), 839-845. 


\section{요 약}

본 연구는 염색 공정의 표준화와 재현성을 확립하기 위해 홍화 황색소의 모섬유에 대한 염색성을 조사 하는데 목적이 있다. 홍화 황색소는 물로 추출한 후 농축, 동결건조하여 분말상태로 만들어 사용하였다. 염색 온도 및 시간, 염료 농도, 염액의 $\mathrm{pH}$ 등에 따른 염착성과 색상 변화에 대해 조사하였으며, 세탁 및 일광견뢰도를 평가하였다. 염착량은 $50^{\circ} \mathrm{C}$ 까지 서서히 증가하다가 이후 급격히 증가하여 $90^{\circ} \mathrm{C}$ 에서 최고 값을 나타냈다. 염착은 초기 10 분 이내에 빠르게 일어났으며 이후 서서히 증가하다가 40 60분 사이에 평 형에 도달하였다. 염료 농도가 증가함에 따라 염착량이 계속 증가하여 점점 진하고 어두운 노랑색이 되었 다. 산성 조건에서 염착이 잘 되었으며 $\mathrm{pH} 3.0$ 에서 최대염착량을 보였다. 얻은 결과를 근거로 최적 염색 조건은 $90^{\circ} \mathrm{C}, 40$ 분, $\mathrm{pH} 3.5$ 으로 설정하였으며, 최적 조건에서 염색한 시료들 간의 색차는 $0.53 \sim 1.75$ 로서 재현성이 우수하였다. 후매염은 염착성 증진에 효과가 없었으나, 다양한 톤과 농담의 노랑색을 얻을 수 있었다. 세탁(드라이크리닝)견뢰도는 4/5등급으로 좋은 편이었으나 20 시간 조사 후 일광견뢰도는 $\mathrm{Fe}$ ㄱ $\mathrm{Cu}$ 매염한 경우 $3 / 4$ 등급으로 색차가 가장 적었다. 결과를 종합해 볼 때 매염제가 색상톤을 다양하게 하는 효과는 있었지만, 염착량과 견뢰도 향상에 기여하지 못하였다. 홍화 황색소는 모염색에서 매염제 없이 만 족스러운 결과를 얻을 수 있고, 따라서 환경에 피해를 주지 않을 것으로 사료된다. 